\title{
Population demographics of native and newly invasive populations of the green crab Carcinus maenas
}

\author{
Iain J. McGaw ${ }^{1,2, *}$, Timothy C. Edgell ${ }^{3}$, Michel J. Kaiser ${ }^{4}$ \\ ${ }^{1}$ Ocean Sciences Centre, 1 Marine Lab Road, Memorial University, St John's, Newfoundland A1C 5S7, Canada, \\ ${ }^{2}$ Bamfield Marine Sciences Centre, 100 Pachena Road, Bamfield, British Columbia V0R 1B0, Canada \\ ${ }^{3}$ LGL Limited Environmental Research Associates, 9768 Second Street, Sidney, British Columbia V8L 3Y8, Canada \\ ${ }^{4}$ School of Ocean Sciences, College of Natural Sciences, Bangor University, Menai Bridge, Anglesey LL59 2AB, UK
}

\begin{abstract}
Green crabs Carcinus maenas (L.) are native to north-western Europe, but have been spread globally by humans during the last 200 yr. Reproductively viable populations have been present for $<10 \mathrm{yr}$ in British Columbia, Canada. In the present study, C. maenas were collected from 2 geographically separated locations, Anglesey (UK) and British Columbia (Canada), to compare bodysize and colour distributions between native and newly invasive populations. Crabs were captured using baited traps and collected by hand at both intertidal and shallow subtidal elevations. Crabs from British Columbia were significantly larger than those from Europe. The largest male, $101.1 \mathrm{~mm}$, and the largest female, of $85.4 \mathrm{~mm}$ carapace width, were both captured in British Columbia. The native populations showed a higher frequency of red-coloured crabs than the introduced population, which consisted predominately of green-coloured male crabs. Green-coloured integuments are typical of individuals in the early stages of intermoult. Accordingly, the high frequency of large, greencoloured C. maenas in British Columbia suggests that individuals in this population have an atypically high growth rate and achieve a larger body size and, hence, potentially greater fecundity. Moreover, the scarcity of small C. maenas in British Columbia may indicate that the existing population comprises only the first or second generation of recruits. The observed differences in body size and colour distribution are perhaps indicative of release from an as yet undetermined growth-limiting factor (possibly parasites) and provide a unique opportunity to study the dynamics of a newly invasive population as it recruits and matures.
\end{abstract}

KEY WORDS: Carcinus maenas $\cdot$ Crab $\cdot$ Distribution $\cdot$ Colour form $\cdot$ Moult stage

\section{INTRODUCTION}

The European green crab Carcinus maenas (L.) is native to northwest Europe and the western Mediterranean (Crothers 1968). Because of its tolerance of a wide range of environmental conditions, it has become a wide-spread invasive species, with the potential to outcompete and displace native crab species (Broekhuysen 1936, Grosholz \& Ruiz 1995, Grosholz et al. 2000). C. maenas is also an important predator of molluscs, with the potential to affect the population size and structure of both natural populations (Edgell \& Rochette 2008) and commercial farming operations (Jensen \& Jensen 1985), for which it is considered a pest species.

With the increase in international trade during the last century, Carcinus maenas has been distributed around the globe, most probably via transfers of aquaculture species, such as oysters, and ship ballast water. Reproductively viable populations have been reported in Australia, South Africa and North America, while isolated specimens have been discovered in 
South America, SE Asia and Japan (Carlton \& Cohen 2003). Specimens of $C$. maenas were first found on the west coast of North America in 1989, when a number of individuals were captured in San Francisco Bay (Cohen et al. 1995). In 1997, populations were discovered along the coast of Oregon and Washington (Behrens-Yamada \& Hunt 2000). The first specimens in Canada were reported from Barkley Sound, British Columbia, in 1999; these 5 individuals were assumed to be stray recruits, and there was no evidence of an established population (Behrens-Yamada \& Gillespie 2008). However, in 2006, several reproductive populations were discovered on the west coast of Vancouver Island (Gillespie et al. 2007). These individuals probably represented a cohort of crabs that settled in 2005, and evidence suggests that these populations may now persist in this area (Behrens-Yamada \& Gillespie 2008).

In its native range, Carcinus maenas typically reaches a maximum size of $86 \mathrm{~mm}$ carapace width (CW) (Crothers 1968), although a single specimen of $100 \mathrm{~mm}$ has been reported from western Sweden (Behrens-Yamada 2001). The colour of its integument varies from a pale yellow-green through orange to a deep red-brown, which is most apparent on the underside and legs (Crothers 1968). The red-brown colour accumulates during a prolonged intermoult period or possibly at terminal anecdysis (Kaiser et al. 1990, McGaw et al. 1992, Reid et al. 1997). These redcoloured individuals are thought to represent the reproductive phase, whereas green-coloured individuals are actively moulting and resources are diverted toward growth (Reid et al. 1997, Wolf 1998, Styrishave et al. 2004).

Given that Carcinus maenas has only been established in Barkley Sound for a few years, we had a unique opportunity to study the demographics (size, sex and colour) of this population. While a number of studies have characterized the population spread of $C$. maenas in the Pacific Northwest (reviewed in BehrensYamada 2001, Behrens-Yamada \& Gillespie 2008), they have not compared the size and colour distributions of a newly invasive cohort with those of native populations from Europe.

\section{MATERIALS AND METHODS}

Carcinus maenas were collected between April and September, primarily using baited net traps; however, because trapping can select for larger-sized individuals (Miller 1990, Ihde et al. 2006), we also supplemented trapping with hand collection (turning rocks in the intertidal and snorkeling) methods. Crabs were collected from their native range in 1989 and 1990 at
3 different sites in the Menai Strait, Anglesey, UK $\left(53^{\circ} 13^{\prime} 36^{\prime \prime} \mathrm{N}, 4^{\circ} 09^{\prime} 24^{\prime \prime} \mathrm{W}\right.$; $53^{\circ} 13^{\prime} 20^{\prime \prime} \mathrm{N}, 4^{\circ} 10^{\prime} 17^{\prime \prime} \mathrm{W}$; $53^{\circ} 07^{\prime} 45^{\prime \prime} \mathrm{N}, 4^{\circ} 18^{\prime} 31^{\prime \prime} \mathrm{W}$ ), and at 3 sites in Barkley Sound, British Columbia, Canada, during 2008 and $2009 \quad\left(49^{\circ} 01^{\prime} 43^{\prime \prime} \mathrm{N}, \quad 125^{\circ} 18^{\prime} 16^{\prime \prime} \mathrm{W}_{\text {; }} \quad 49^{\circ} 02^{\prime} 13^{\prime \prime} \mathrm{N}\right.$, $\left.125^{\circ} 19^{\prime} 54^{\prime} \mathrm{W}_{i} 49^{\circ} 02^{\prime} 36^{\prime \prime} \mathrm{N}, 125^{\circ} 09^{\prime} 36^{\prime \prime} \mathrm{W}\right)$. Because the trapping activities at the 2 locations were separated by a significant interval, with the potential for long-term effects associated with changes in local seawater temperature, additional trapping was carried out in the Menai Strait from December to April, 2009 to 2010, in order to determine whether any significant change in population demography had occurred over the $20 \mathrm{yr}$ period. The collection methods and site topography were replicated as closely as possible between the UK and Canadian sites. Collections were made on 2 days each month, using 2 different sizes of trap at each site. In the UK, small cylindrical netlon traps of $0.5 \mathrm{~cm}$ mesh size were $60 \mathrm{~cm}$ in length and $30 \mathrm{~cm}$ diameter, with 2 entrances of $7 \mathrm{~cm}$ each. The larger traps constructed of $2 \mathrm{~cm}$ mesh were $120 \mathrm{~cm}$ in length and $60 \mathrm{~cm}$ diameter, with 2 entrances of $15 \mathrm{~cm}$ each. Folding oval fish traps were used in Canada, the smaller traps $(0.9 \mathrm{~cm}$ mesh) were $60 \mathrm{~cm}$ in length, $45 \mathrm{~cm}$ wide and $30 \mathrm{~cm}$ in height, with 2 entrances of $7 \mathrm{~cm}$ each. The larger traps $(2.5 \mathrm{~cm}$ mesh) were $90 \mathrm{~cm}$ in length, $60 \mathrm{~cm}$ wide and $60 \mathrm{~cm}$ in height, with 2 entrances of $15 \mathrm{~cm}$ each. Because low salinity can affect both size- and colour-distribution patterns in this species, all the sites chosen were situated away from the influence of freshwater (salinity $>22$; McGaw \& Naylor 1992a,b) and consisted of a similar habitat of large boulders on gravel with fucoid and kelp seaweeds. Collections were made from mean mid-water level to approximately $2 \mathrm{~m}$ below mean low water.

Crabs were measured to the nearest $0.1 \mathrm{~mm}$ across the widest part of the carapace (from the outside of the first spine), and the sex and colour (green, orange, or red) was noted. Detailed measurements of the larger specimens were also made. In order to avoid recapture of the same individuals, the crabs were not returned to the collection sites.

We tested for factors that affected carapace size using a Kruskal-Wallis test on ranked data. Fixed-effect tests included crab origin (UK vs. Canada), sex (male vs. female) and integument colour (green vs. red). To balance the analysis, we randomly selected 208 individuals from each origin $\times$ sex $\times$ colour group $-n=208$ was the smallest sample size in any one of these groups. Because of a significant origin $\times$ sex $\times$ colour interaction term $(p=0.006)$, the analysis was broken down to test for: (1) the effect of origin on carapace size, between UK and Canadian populations, and (2) the effects of sex and colour on carapace width within each region separately. 


\section{RESULTS}

A total of 6890 crabs were collected; 5096 crabs were collected in the Menai Strait, and 1794 from Barkley Sound. Initially, crabs were divided into 3 colour groupings: green, orange, or red. Statistical analysis showed, for the most part, that size distributions for orange and red crabs were similar, suggesting they were of the same cohort. Data for orange and red coloured crabs were, therefore, pooled and termed red. Colour distributions differed between the 2 areas. In the Menai Strait, $55 \%$ of males were green and $45 \%$ were red, while $36 \%$ of females were green and $64 \%$ were red. In Barkley Sound, $84 \%$ of male crabs were green and $16 \%$ red, while for females $47 \%$ were green and $53 \%$ were red (Table 1 ).

Red crabs were significantly larger than green crabs at both locations (Table 1). In Barkley Sound, the average red male was $3 \%$ larger than the average green male ( $2 \%$ difference between median values) and the average red female was $7 \%$ larger than green females (5\% difference between median values). In the Menai Strait, the average red male was $13 \%$ larger than the average green male $(11 \%$ difference between medians) and the average red female was $21 \%$ larger than green females $(20 \%$ difference between median values). Moreover, crabs from Barkley Sound were 39\% larger than those from the UK $(\mathrm{p}<0.0001)$ (Table 1). In Barkley Sound, $71 \%$ of crabs were male, this was higher than the percentage of males $(60 \%)$ found in the Menai Strait. The latter may contribute to the greater proportion of large crabs in Canada, because male crabs were significantly larger than females in both regions (Fig. 1).

Since the collections at the 2 sites were separated by a significant time period, additional collections were carried out in the Menai Strait between December and April, 2009 to 2010, and compared with the earlier

Table 1. Carcinus maenas. Descriptive data for 2 populations of C. maenas. Mean size $( \pm \mathrm{SD})$ and minimum, maximum and median sizes (in $\mathrm{mm})$, and the percentage of green- versus red-coloured individuals in a given population

\begin{tabular}{|c|c|c|c|c|c|}
\hline \multirow[t]{2}{*}{ Population } & \multicolumn{4}{|c|}{$\longrightarrow$ Size $(\mathrm{mm})$} & \multirow[t]{2}{*}{ Percentage } \\
\hline & Mean \pm SD & Minimum & Maximum & Median & \\
\hline \multicolumn{6}{|l|}{ United Kingdom } \\
\hline Green males & $51.3 \pm 13.6$ & 8.2 & 83.1 & 53.4 & 55 \\
\hline Red males & $58.2 \pm 9.8$ & 17.0 & 79.3 & 59.2 & 45 \\
\hline Green females & $43.1 \pm 12.7$ & 8.0 & 71.0 & 45.1 & 36 \\
\hline Red females & $52.2 \pm 9.0$ & 22.4 & 74.1 & 54.1 & 64 \\
\hline \multicolumn{6}{|l|}{ Western Canada } \\
\hline Green males & $76.1 \pm 11.2$ & 24.0 & 101.1 & 78.3 & 84 \\
\hline Red males & $78.2 \pm 8.6$ & 44.1 & 94.1 & 80.1 & 16 \\
\hline Green females & $60.1 \pm 11.1$ & 29.9 & 85.4 & 62.1 & 47 \\
\hline Red females & $64.4 \pm 8.9$ & 39.9 & 82.5 & 65.4 & 53 \\
\hline
\end{tabular}

samples collected during the same months. Differences in size were apparent between green-coloured males and red-coloured females; however, these differences were not substantial. The mean $( \pm \mathrm{SD})$ size of green-coloured males collected from 1989 to 1990 was $48.7 \pm 8.6 \mathrm{~mm}$ compared with the $50 \pm 13.2 \mathrm{~mm}$ of green males measured from 2009 to 2010 ( $t$-test, p = 0.044). Red females collected from 1989 to 1990 were larger than red females collected 20 yr later $(50.3 \pm 9.8$ vs. $46.8 \pm 7.1 \mathrm{~mm}$; $t$-test, $\mathrm{p}=0.008)$. There was no significant difference in the mean sizes of red-coloured males $\left(54.9 \pm 11.3\right.$ vs. $53.4 \pm 7.7 \mathrm{~mm}_{\text {; }} t$-test, $\left.\mathrm{p}=0.46\right)$ or green-coloured females $(40.7 \pm 13.9$ vs. $42.4 \pm 5.6 \mathrm{~mm}$; $t$-test, $\mathrm{p}=0.18$ ).

The largest male and female crabs in our samples were both captured in Barkley Sound. The male crab had a green integument, a CW of $101.1 \mathrm{~mm}$, a carapace length (rostrum to 1st abdominal segment) of $74.8 \mathrm{~mm}$, and weighed $247.8 \mathrm{~g}$. Its crusher claw height was $40.2 \mathrm{~mm}$ and its length was $45.2 \mathrm{~mm}$. The cutter claw was $29.2 \mathrm{~mm}$ high and $36.3 \mathrm{~mm}$ in length.

The largest female crab also had a green integument, $85.4 \mathrm{~mm} \mathrm{CW}$, a carapace length of $60.6 \mathrm{~mm}$ and weighed $124.3 \mathrm{~g}$. The right chela was $23 \mathrm{~mm}$ in height and $31.3 \mathrm{~mm}$ in length. The left chela was $18.9 \mathrm{~mm}$ in height and $27.8 \mathrm{~mm}$ in length. The pereiopods on both specimens were intact, and there was no evidence of damage or epibiont fouling on the carapace.

\section{DISCUSSION}

To date, the maximum size attained by green crabs Carcinus maenas appears highly consistent, both in its native range and in locations where it has become established (Australia, east coast of North America, Patagonia, South Africa) and is classified as an invasive species (Ropes 1968, Le Roux et al. 1990, Hidalgo et al. 2005, Audet et al. 2008). There are reports of an individual green crab from British Columbia that attained $106 \mathrm{~mm}$ CW (T. Therriault \& C. DiBacco, DFO Canada, pers. comm.); maximum sizes of 110 to $115 \mathrm{~mm}$ CW may, therefore, be attainable (Grosholz \& Ruiz 1996). In Barkley Sound, this species reached unusually large sizes; $>30 \%$ of the 1794 crabs collected were $80 \mathrm{~mm}$ or larger, whereas in the UK only 3 of the 5096 crabs collected $(0.06 \%)$ had carapace widths exceeding $80 \mathrm{~mm}$. The largest male collected in Barkley Sound was 101.1 mm CW; while not the largest reported specimen, it is within the upper range of 

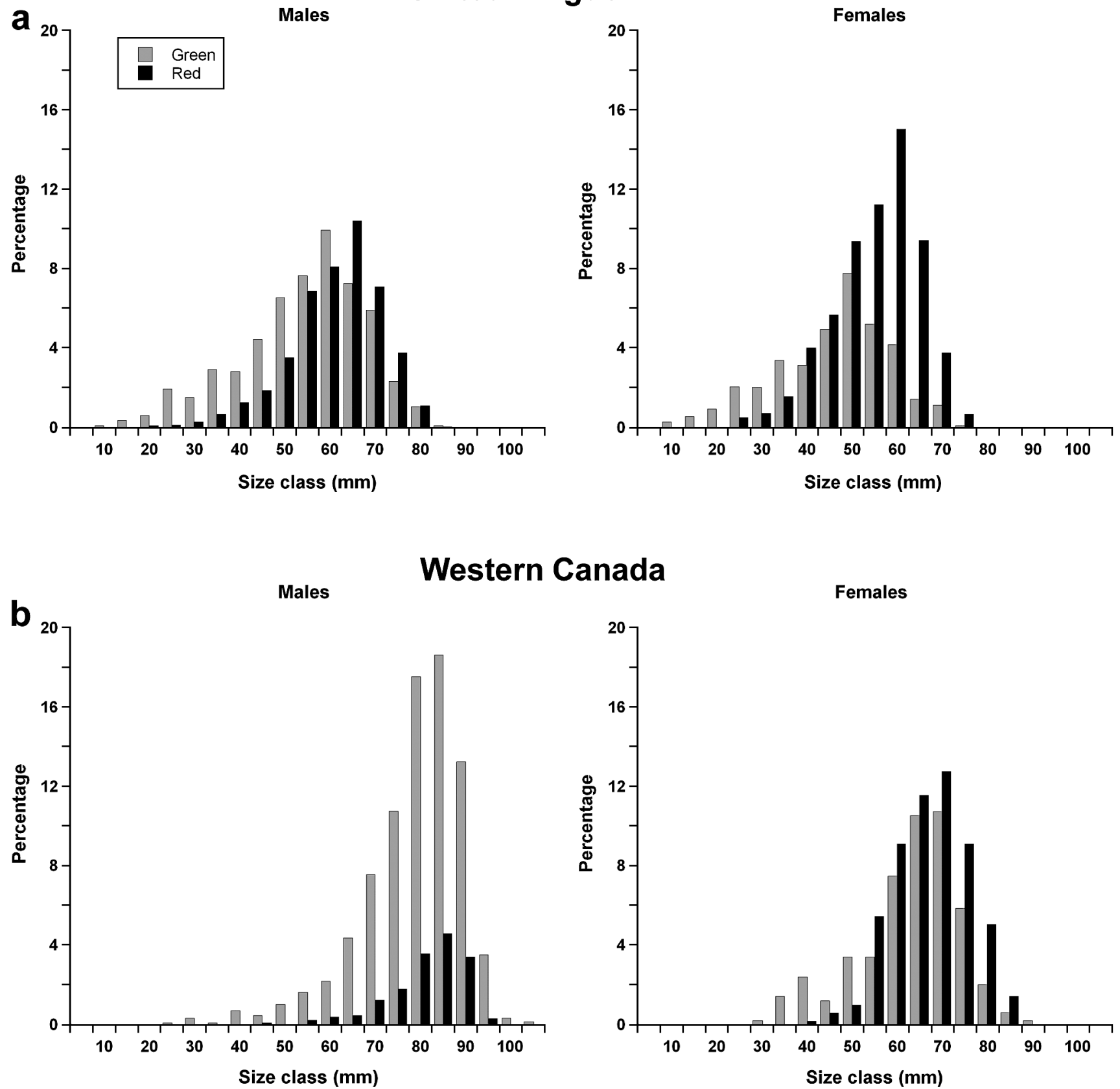

Females

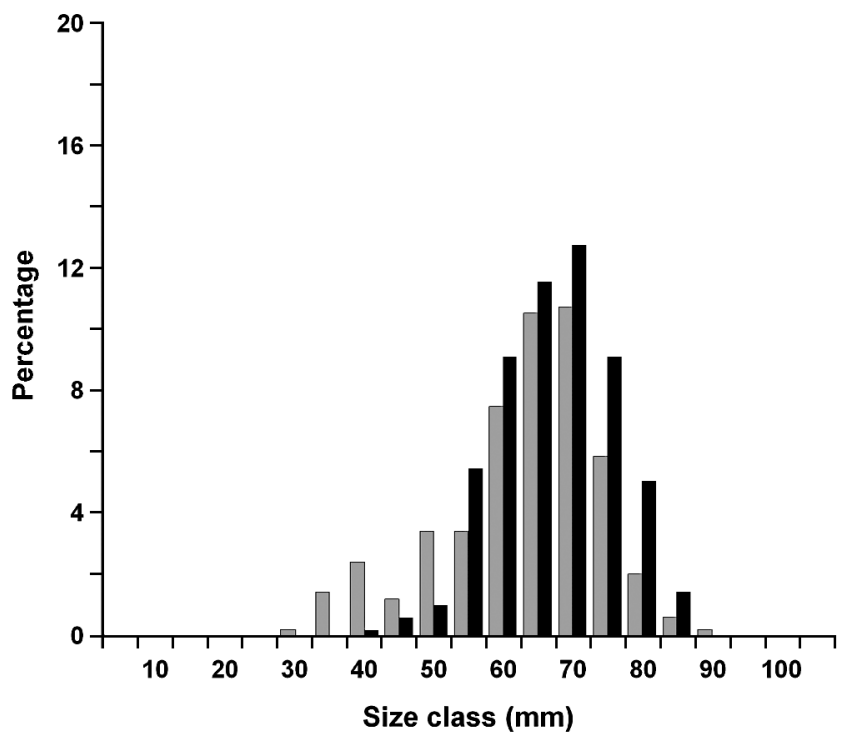

Fig. 1. Carcinus maenas. Percentage of green- and red-coloured males and females in $5 \mathrm{~mm}$ size classes. Crabs were collected in traps and by hand in (a, upper panels) Menai Straits, Gwynedd, UK ( $\mathrm{n}=5096)$, and (b, lower panels) Barkley Sound, British Columbia, Canada $(\mathrm{n}=1792)$

reported maximum sizes. In general, females were smaller than males, and, although they may reach >90 mm CW (J. Drewery, FRS Marine Labs, pers. comm.), the $85.4 \mathrm{~mm} \mathrm{CW}$ female specimen also appears to be one of the largest published records for this species.

The larger size of crabs on the west coast of North America has been noted previously, but, to date, no definitive conclusions for this observation have been drawn (Grosholz \& Ruiz 2003). The west coast populations are descended from crabs from the east coast of North America, but, at present, there is no evidence to suggest that these were genetically distinct populations (Bagley \& Geller 2000). Low winter sea temperatures $\left(<5^{\circ} \mathrm{C}\right)$ limit the growth and reproductive season (Behrens-Yamada 2001) and can stop recruitment and increase mortality of older, larger individuals (Berrill 
1982). However, seawater temperatures in the Menai Strait (Harvey 1972) and Barkley Sound (Bamfield Marine Sciences Centre, Ocean News Records) are similar, and in South Africa, where water temperatures are warmer and the growing season is longer, the crabs are no larger than their native counterparts (Le Roux et al. 1990). Prey items are also plentiful in both areas, and there is little evidence to suggest that growth in crabs from Europe is limited by food availability (Klein Breteler 1975, Berrill 1982). It has been postulated that a lack of predators on the North American west coast may allow Carcinus maenas to attain larger sizes (Grosholz \& Ruiz 2003). However, most animals that prey upon crabs are opportunistic feeders (Torchin et al. 2001), and there are a large number of fish species (Hart 1973) and $>20$ species of decapod crustaceans that are likely to eat C. maenas (Hunt \& Behrens-Yamada 2003). The most plausible explanation for the size differences is that a release from parasites, which slow growth, allows crabs on the west coast to grow more rapidly and attain a larger size (Torchin et al. 2001). This phenomenon is not only limited to C. maenas, but appears to apply to a number of other invasive phyla (Torchin et al. 2001).

The underside of Carcinus maenas varies in colour from a pale green, through orange, to a deep redbrown (Kaiser et al. 1990, McGaw et al. 1992). The red colouration builds-up during a prolonged intermoult period, as the pigments in the carapace denature (Reid et al. 1997, Taylor et al. 2009). However, all crabs, irrespective of initial colour, turn green immediately after moult. In general, red crabs tend to be larger than their green counterparts and are thought to direct energy towards reproduction rather than growth (Reid et al. 1997). In the Menai Strait, the green-coloured crabs were $17.3 \%$ smaller than red-coloured crabs, a significantly greater difference than the $5 \%$ size variation observed for Barkley Sound populations. The high proportion of these large green-coloured crabs in Barkley Sound suggests that the population is in an actively growing rather than a reproductive phase (Reid et al. 1997, Wolf, 1998). The fact that only 5 pre-copula pairs and 4 berried females were found during specimen collections further substantiates this assertion.

The reason why crabs in Barkley Sound appear to exhibit short intermoult periods and, thus, rapid growth is unclear. Conspecifics feed on small crabs, and the presence of large individuals can, thus, cause the small crabs to delay moulting, because they can be more easily preyed upon when the shell is soft (Klein Breteler 1975). When Carcinus maenas settles in a previously unoccupied zone, they are larger than subsequent cohorts, because they are not moulting-limited by larger individuals (Klein Breteler 1975). This appears to be a plausible explanation for the predomi- nance of large green-coloured crabs in Barkley Sound. We also hypothesize that, because of the large number of potential crustacean predators/competitors in Barkley Sound, C. maenas diverts energy towards growth to gain a size-based predation refuge. This would allow them to avoid predation and possibly outcompete native crabs, such as Cancer gracilis (Dana, 1852) and the smaller Cancer productus (Randall, 1839), which occur sympatrically (Jensen \& Jensen 1985, T. Therriault \& C. DiBacco pers. comm.). Our preliminary experiments support this idea: when 2 size groups of C. maenas (45 to $60 \mathrm{~mm}$ and 80 to $95 \mathrm{~mm}$ ) were introduced into a tank with C. productus of 120 to $160 \mathrm{~mm}$, the smaller individuals suffered $50 \%$ mortality within $24 \mathrm{~h}$, whereas none of the crabs $>80 \mathrm{~mm}$ were injured (I. J. McGaw unpubl. obs.).

It could be argued that differences in carapace colour between the regions were a result of other factors, such as consumption of different food types; however, the diet of Carcinus maenas tends to be fairly conserved when comparing native and invasive populations (Grosholz \& Ruiz 1996). In addition, the red colour is not the only characteristic of a prolonged intermoult; thicker or worn carapaces with heavier epibiont loads (McGaw et al. 1992) and discoloured gills (Legeay \& Massabuau 2000) are also indicative of a prolonged intermoult. These were not evident in the large green-coloured crabs in Barkley Sound. Observation of the setae of the exopodites (O'Halloran \& O'Dor 1988, Kaiser et al. 1990) of 6 red- and 8 greencoloured crabs from Barkley Sound confirmed that red crabs were in mid- to late ' $\mathrm{C}$ ' stage, whereas the green crabs were in early ' $\mathrm{C}$ ' stage, which again suggests that individuals in the population moulted more frequently, channelling energy towards growth rather than reproduction.

The demographics of the western Canadian cohort have already changed. In 2006 the population was much smaller, and only $6 \%$ of individuals were red in colour (Gillespie et al. 2007). The increase in the percentage of red-coloured individuals can be partially explained because the red colouration accumulates as the crabs age (Gillespie et al. 2007). Nevertheless, the high number of green-coloured male crabs in the large size classes $(>80 \mathrm{~mm})$ and the fact that the red crabs had very few epibionts on the carapace suggests that they are still moulting relatively frequently (McGaw et al. 1992). The lack of small greencoloured individuals shows that recruitment was low after 2007, and the population is primarily composed of a single ageing cohort. If this species persists and recruits further in this area, it will be of interest to see how the population characteristics change over time with respect to those of more established and native populations. 
Acknowledgements. We thank the director and staff of the Bamfield Marine Sciences Centre for the use of facilities. We also thank Drs Sylvia Behrens-Yamada, Claudio DiBacco, Greg Jensen and Tom Therriault for helpful discussion. Dermott Crowley and Berwyn Roberts assisted with field collections in the Menai Strait in 2009/2010.

\section{LITERATURE CITED}

Audet D, Miron G, Moriyasu M (2008) Biological characteristics of a newly established green crab (Carcinus maenas) population in the southern Gulf of St Lawrence, Canada. J Shellfish Res 27:427-441

Bagley MJ, Geller JB (2000) Microsatellite DNA analysis of native and invading populations of European green crabs. In: Pederson J (ed) Marine bioinvasions: proceedings of the 1st national conference. Massachusetts Sea Grant, Cambridge, MA

Behrens-Yamada S (2001) Global invader: the European green crab. Oregon Sea Grant, Corvallis, OR

Behrens-Yamada S, Gillespie GE (2008) Will the European green crab (Carcinus maenas) persist in the Pacific Northwest? ICES J Mar Sci 65:725-729

Behrens-Yamada S, Hunt C (2000) The arrival and spread of the European green crab Carcinus maenas in the Pacific Northwest. Dreissena! 11:1-7

Berrill M (1982) The life cycle of the green crab Carcinus maenas at the northern end of its range. J Crustac Biol 2: 31-39

Broekhuysen GJ (1936) On development, growth and distribution of Carcinus maenas (L.). Arch Neerl Zool 2:257-339

Carlton JT, Cohen AN (2003) Episodic global dispersal in shallow water marine organisms: the case history of the European shore crabs Carcinus maenas and Carcinus aestuarii. J Biogeogr 30:1809-1820

Cohen AN, Carlton JT, Fountain M (1995) Introduction, dispersal and potential impacts of the green crab Carcinus maenas in San Francisco Bay. Mar Biol 122:225-237

Crothers JH (1968) The biology of the shore crab Carcinus maenas (L.): life of the adult crab. Field Stud 2:597-614

Edgell TC, Rochette R (2008) Differential snail predation by an exotic crab and the geography of shell-claw covariance in the Northwest Atlantic. Evolution 62:1216-1228

Gillespie GE, Phillips AC, Paltzat DL, Therriault TW (2007) Status of the European green crab in British Columbia, 2006. Can Tech Rep Fish Aquat Sci No. 2700

Grosholz ED, Ruiz GM (1995) Spread and potential impact of the recently introduced European green crab, Carcinus maenas, in central California. Mar Biol 122:239-247

Grosholz ED, Ruiz GM (1996) Predicting the impact of introduced marine species: lessons from the multiple invasions of the European green crab. Biol Conserv 78:59-66

Grosholz ED, Ruiz GM (2003) Biological invasions drive size increases in marine estuarine invertebrates. Ecol Lett 6: 700-705

Grosholz ED, Ruiz GM, Dean CA, Shirley KA, Maron JL, Connors PG (2000) The implications of a nonindigenous marine predator in a California bay. Ecology 81:1206-1224

Hart JL (1973) Pacific fishes of Canada. Fisheries Research Board of Canada, Ottawa, ON

Harvey JG (1972) Water temperatures at the Menai Bridge pier 1955-1968. Ocean Dyn 25:202-215
Hidalgo FJ, Baron PJ, Orensanz JM (2005) A prediction come true: the green crab invades the Patagonian coast. Biol Invas 5:547-552

> Hunt CE, Behrens Yamada S (2003) Biotic resistance experienced by an invasive crustacean in a temperate estuary. Biol Invas 5:33-43

> Ihde TF, Frusher SD, Hoenig JM (2006) Do large rock lobsters inhibit smaller ones from entering traps? A field experiment. Mar Freshw Res 57:665-674

Jensen KT, Jensen JN (1985) The importance of some epibenthic predators on the diversity of juvenile benthic macrofauna in the Danish Wadden Sea. J Exp Mar Biol Ecol 89:157-174

> Kaiser MJ, Hughes RN, Reid DG (1990) Chelal morphometry, prey size selection and aggressive competition in green and red forms of Carcinus maenas (L.). J Exp Mar Biol Ecol 140:121-134

Klein Breteler WCM (1975) Growth and moulting of juvenile shore crabs, Carcinus maenas, in a natural population. Neth J Sea Res 9:86-99

Le Roux PJ, Branch GM, Joska MAP (1990) On the distribution, diet and possible impact of the invasive European shore crab Carcinus maenas (L.) along the South African coast. S Afr J Mar Sci 9:85-93

Legeay A, Massabuau JC (2000) The ability to feed in hypoxia follows a seasonally dependent pattern in shore crab Carcinus maenas. J Exp Mar Biol Ecol 247:113-129

McGaw IJ, Naylor E (1992a) Salinity preference of the shore crab Carcinus maenas in relation to coloration during intermoult and to prior acclimation. J Exp Mar Biol Ecol 155:145-159

> McGaw IJ, Naylor E (1992b) Distribution and rhythmic locomotor patterns of estuarine and open shore populations of Carcinus maenas. J Mar Biol Assoc UK 72:599-609

McGaw IJ, Kaiser MJ, Naylor E, Hughes RN (1992) Intraspecific morphological variation related to the moult-cycle in colour forms of the shore crab Carcinus maenas. J Zool 228:351-359

> Miller RJ (1990) The effectiveness of crab and lobster traps. Can J Fish Aquat Sci 47:1228-1251

> O'Halloran MJ, O'Dor RK (1988) Molt cycle of male snow crabs Chionoectes from observation of external features, setal changes and feeding behaviour. J Crustac Biol 8:164-176

> Reid DG, Abello P, Kaiser MJ, Warman CG (1997) Carapace colour, intermoult duration and the behavioural and physiological ecology of the shore crab, Carcinus maenas. Estuar Coast Shelf Sci 44:203-211

Ropes JW (1968) The feeding habits of the green crab, Carcinus maenas (L). Fish Bull 67:183-203

> Styrishave B, Rewitz K, Andersen O (2004) Frequency of moulting by shore crabs Carcinus maenas (L) changes their colour and their success in mating and physiological performance. J Exp Mar Biol Ecol 313:317-336

Taylor GM, Keyghobadi N, Schmidt PS (2009) The geography of crushing: variation in claw performance of the invasive crab Carcinus maenas. J Exp Mar Biol Ecol 377:48-53

Torchin ME, Lafferty KD, Kuris AM (2001) Release from parasites as natural enemies: increased performance of a globally introduced crab. Biol Invas 3:333-345

Wolf F (1998) Red and green colour forms in the common shore crab Carcinus maenas (L.) (Crustacea: Brachyura: Portunidae): theoretical predictions and empirical data. J Nat Hist 32:1807-1812 